\title{
Myc-Foxo, a link between glutaminolysis and autophagy
}

\author{
Sheri Zola, Paola Bellosta* \\ From Metabolism, diet and disease \\ Washington, DC, USA. 29-31 May 2012
}

Our recent observations that $\mathrm{dMyc}$ expression in the Drosophila FB -a metabolic tissue with similar physiological functions as mammalian adipose tissue and liver remotely influences the development of the whole animal, allows us to explore its function in a living growing organism. dMyc in FB increases animal survival, which correlates with an increased level of autophagy, especially visible in FB from animals under starvation. Our preliminary data show that in addition to enzymes responsible for glycolysis, dMyc upregulates in FB the expression of the putative glutamine transporter slcA7/minidiscs and of glutaminase, the enzyme that converts glutamine to alfaketoglutarate with the production of ammonia. By varying the nutrient availability, we found that $\mathrm{dMyc}$ expression induces the accumulation of high levels of ammonia in the supernatant of S2 cells. Ex-vivo cultures of FB incubated in these supernatants exhibited autophagy, suggesting that dMyc is responsible for the expression of soluble proautophagic factors, possibly ammonia. In FB autophagy is particularly evident during starvation, conditions where $\mathrm{dFOXO}$ transcription sustains dMyc expression. Using genetic manipulation of components of glutamine metabolism we are currently exploring if the relationship between dMyc and $\mathrm{dFOXO}$ in FB affects ammonia production and autophagy via glutamine catabolism. With these experiments we aim to understand whether FOXO regulates Myc to induce glutamine signaling, placing FOXO-function relevant for glutaminolysis, which is one of the most relevant survival pathways in tumor cells.

Published: 1 June 2012

Dept of Genetics and Developments, Columbia University Med Center, New York, NY, 10032, USA

\section{Biomed Central}

(0) 2012 Zola and Bellosta; licensee BioMed Central Ltd. This is an Open Access article distributed under the terms of the Creative Commons Attribution License (http://creativecommons.org/licenses/by/2.0), which permits unrestricted use, distribution, and reproduction in any medium, provided the original work is properly cited.
doi:10.1186/1753-6561-6-S3-P6

Cite this article as: Zola and Bellosta: Myc-Foxo, a link between glutaminolysis and autophagy. BMC Proceedings 2012 6(Suppl 3):P6.

Submit your next manuscript to BioMed Central and take full advantage of:

- Thorough peer review

- No space constraints or color figure charges

- Immediate publication on acceptance

- Inclusion in PubMed, CAS, Scopus and Google Scholar

- Research which is freely available for redistribution Submit your manuscript at
www.biomedcentral.com/submit C Biomed Central
- Convenient online submission 